\title{
The evolution of farming networks in a fragile institutional environment: the case of Argentina
}

\author{
S.I. Senesi ${ }^{1}$, H. Palau ${ }^{1}$, F.R. Chaddad ${ }^{2,3}$ and M. Daziano ${ }^{1}$ \\ ${ }^{1}$ Food and Agribusiness Program. School of Agronomy-UBA, Av. San Martín 4453, CP: 1417, Ciudad de Buenos Aires, Argentina; \\ ${ }^{2}$ University of Missouri, 125 Mumford Hall,Columbia, MO 65211-6200, USA, ${ }^{3}$ Insper University, Rua Quatá, 300, Vila Olímpia, \\ CEP 04546-042, São Paulo, SP, Brazil; ssenesi@agro.uba.ar
}

RESEARCH ARTICLE

\begin{abstract}
In Argentina, farming traditionally took place in small and medium-sized family farms, mostly by means of their own land, labour, capital (financial, machinery, etc.) and entrepreneurship. Farmers owned enough equipment to cope with all the activities required for the production cycle. This traditional family farm model is the dominant organisational form in agriculture in almost every country. However, the way of managing, contracting and organising agriculture in Argentina has changed since the 1990 s as a result of several institutional innovations. Even though the 2002 economic crisis created a highly uncertain scenario, farm production continued to expand and new organisational forms appeared. Since 2007, institutional changes (more related to Government intervention) had a negative impact on production and organisational forms. These different periods and scenarios enable us to explore the dynamics and interrelationships of the different institutional, organisational and technological environments. The paper discusses organisational adaptation in the agriculture sector as a response to radical changes in the technological and institutional environments, in a context of increased international demand for agricultural commodities.
\end{abstract}

Keywords: hybrid forms, networks, innovations, commodities, adaptation

\section{Introduction}

In Argentina, farming traditionally took place in small and medium-sized family farms, mostly by means of their own land, labour, capital (financial, machinery, etc.) and entrepreneurship. Farmers owned enough equipment to cope with all the activities required for the production cycle. This traditional family farm model is the dominant organisational form in agriculture in almost every country.

Since the 1990s, however, a new scenario has emerged (Ordóñez and Nichols, 2003): the economy was deregulated and opened up to globalisation, and free market policies were adopted - the Convertibility law, which tied the Argentine peso to the US dollar; privatisation of Stateowned organisations; import tariff reduction. Under this new scenario, the Argentine economy managed to achieve a degree of stability that created a business-friendly environment. In addition, the convertibility law with a fixed exchange rate fostered investments in imported machinery and cutting-edge technology.

New organisational forms in agriculture emerged in this economic environment, which significantly changed the nature of relationships between agrifood system participants. Some agents specialised in custom agricultural services - such as seeding, spraying and harvesting - and invested in modern farming equipment and machinery. Some landowners or farmers without land also invested in modern machinery and leveraged their knowledge and resources on new leased lands thereby controlling larger farming operations. During the 1990s, while farming margins were being squeezed, an increase in production scale was necessary within agriculture to reduce fixed and variable costs, and geographic diversification helped mitigate production risks (mainly associated with climatic factors).

The 2001/2002 economic crisis in Argentina brought the financial system to a halt and access to credit was reduced to almost zero. Institutional hazards resulted in fewer incentives for farmers to invest in fixed assets. In order to continue their farming operations, contractors and producers tinkered with new hybrid forms in which they incorporated 'partners' who supplied the financial capital necessary for farming. These new hybrids blossomed during the 2002-2007 period when international commodity 
prices boomed and devaluation of the Argentine peso led to relatively lower costs between 2002-2005.

After this boom period, the institutional environment started to change once again with increased government intervention: price controls, restrictions on export volumes, tax increases (especially those related to commodity exports) and tighter fiscal control. In addition, higher costs for farm inputs, energy, labour and freight started to squeeze margins from 2008 onwards, as a result of which there have been lower incentives for investors.

The objective of this paper is to describe the evolution of the agricultural production sector in Argentina since the early 1990s, focusing on the interplay between changes in the institutional environment and organisational and technological change.

The paper is organised as follows. In the next two sections, the authors outline the theoretical framework and methods used in the paper. Subsequently, there is a description of the emergence and evolution of hybrid forms in three different periods with marked differences in their institutional environments. Then, the paper introduces a discussion on the interplay between the institutional, organisational and technological environments and how they have affected agricultural production and productivity since 1990 . The paper concludes with a brief summary and queries for future research.

\section{Theoretical framework}

The analysis of the recent evolution of the Argentine agricultural production sector is based on the new institutional economics (NIE) approach. In particular, the paper follows two NIE pathways introduced by Joskow $(1995,2004)$ and Williamson (2000): the institutional analysis and the governance structure analysis (Figure 1).

According to this model, the first level of institutional analysis is the social embeddedness level. "This is where the norms, customs, mores, traditions, etc. are located' (Williamson, 2000: 596). This has a strong relationship with trust and compliance to agreements between agents. The second level encompasses the basic institutional environment or what Williamson calls 'the formal rules of the game.'

$$
\text { Level } \quad \text { Frequency (years) Purpose }
$$

\begin{tabular}{|c|c|c|c|}
\hline L1 & $\begin{array}{l}\text { Embeddedness: } \\
\text { informal institutions, } \\
\text { costums, traditions, } \\
\text { norms, religion }\end{array}$ & $100-1000$ years & $\begin{array}{c}\text { Spontaneous } \\
\text { (often non-calculative) }\end{array}$ \\
\hline L2 & $\begin{array}{l}\text { Institutional } \\
\text { environment: formal } \\
\text { rules of the game; } \\
\text { constitution; law }\end{array}$ & $10-100$ years & $\begin{array}{l}1^{\text {st }} \text { order } \\
\text { economizing } \\
\text { (get the institutional } \\
\text { environment right) }\end{array}$ \\
\hline L3 & $\begin{array}{l}\text { Governance: play of } \\
\text { the game; contracts } \\
\text { - governance } \\
\text { structures }\end{array}$ & $1-10$ years & $\begin{array}{l}2^{\text {nd }} \text { order } \\
\text { economizing } \\
\text { (get the governance } \\
\text { structure right) }\end{array}$ \\
\hline L4 & $\begin{array}{l}\text { Resource allocation } \\
\text { and employment } \\
\text { (price and quantities } \\
\text { incentive alignment) }\end{array}$ & Continuous & $\begin{array}{c}3^{\text {rd }} \text { order } \\
\text { economizing } \\
\text { (get the marginal } \\
\text { conditions right) }\end{array}$ \\
\hline
\end{tabular}

L1: Social theory; L2: Economics of property rights; L3: Transaction cost economics; L4: Neoclassical economics

\section{Figure 1. Economics of institutions (Williamson, 2000).}


At this level are defined constitutions, political systems and basic human rights; property rights and their allocation; laws, courts and related institutions to enforce political, human rights and property rights, money, basic financial institutions, and the government's power to tax; laws and institutions governing migration, trade and foreign investment rules; and the political, legal and economic mechanisms that facilitate changes in the basic institutional environment (Joskow, 2004: 10).

This opens up the opportunity for first-order economizing: get the formal rules of the game right (Williamson, 2000: 598).

According to North (1990), institutions matter especially when transaction costs are high. Following Kherallah and Kirsten (2001), it is important to study institutions inasmuch as their level [and the enforcement of current laws] influences economic growth and sustainable economic growth comes from important institutional changes. A fragile institutional environment often results in low levels of investments and technologies due to the uncertainty in appropriating value resulting from investments (North, 1990).

The third level of analysis is where the institutions of governance (or governance structures) are located:

Although property remains important, a perfectly functioning legal system for defining contract laws and enforcing contracts is not contemplated... settlement action is dealt with directly by the parties through private ordering (Williamson, 2000: 599).

Williamson (1991: 271) suggests that 'each viable form of governance - market, hybrid, and hierarchy - is defined by a syndrome of attributes that bear a supporting relation to one another.' Williamson (1991) advances the hypothesis that each generic form of governance is supported by a different form of contract law; and that there are crucial differences between markets, hybrids and hierarchies in how they adapt to changing circumstances and in the use of incentive and administrative control instruments.

Not only does transaction cost economics subscribe to the idea that the transaction is the basic unit of analysis, but governance is an effort to craft order, thereby to mitigate conflict and realize mutual gains (Williamson, 2000: 599).
In the transaction cost perspective, hybrid forms such as the farm production networks analysed in this study are characterised by 'semi-strong incentives, an intermediate degree of administrative apparatus, displays semi-strong adaptations of both kinds and works out of semi-legalistic contract law regime' (Williamson, 1991: 281). Ménard (2004) argues that:

there is indeed a great diversity of agreements among legally autonomous entities doing business together, mutually adjusting with little help from the price system, and sharing or exchanging technologies, information and know-how, capital, products, and services, but without a unified ownership (Ménard, 2004: 348).

Ménard's (2004) central proposition is that hybrid organisations form a 'specific class' of governance structures, combining contractual agreements and administrative entities or 'authorities', with the purpose of coordinating partners' efforts to generate rents from mutual dependence while controlling for the risks of opportunism. The necessity of expanding areas (in order to gain in scale and reduce costs) derived in new contracts by the farmers, reducing uncertainty. On the other hand, financial capital necessity (and availability of this capital but not in formal entities) also derived in new institutional arrangements (Coase, 1937), especially to enforce property rights.

\section{Methodology}

This study focuses on the interplay between analytic levels 2 and 3; in particular how changes at the institutional environment level in Argentina affect the design of governance structures by agents engaged in agriculture.

A qualitative and descriptive research approach is adopted to accommodate the complexity and multi-dimensionality of the research topic. The research has an explanatory level, taking into account that it seeks to develop and clarify concepts and ideas, with a view to formulating more precise problems or hypotheses that can be researched in further studies, besides having a less rigid planning, not applying quantitative techniques and being carried out with more practical concerns (Gil, 1994).

This paper uses phenomenological knowledge as its methodology for studying agribusiness, as recommended by various authors (e.g. Bonoma, 1985; Peterson, 2011; Yin, 1989). This study is designed using the discrete structural analysis approach - that is, a description of the evolution of the agricultural production sector in Argentina through 
the characterisation of its institutional, organisational and technological environments (Williamson, 1991; Zylbersztajn, 1996, 1999). The paper analyses the main institutional changes in Argentina for the periods 19902000, 2001-2007 and 2008-2012. Institutional (rules of law), organisational (players and governance structures adopted) and technological (inputs and processes) environment changes in each period are used to explain subsequent changes in production, productivity and investments in the agricultural production sector.

This paper relies on primary and secondary data for the analysis. Interviews with experts were conducted in 2009 and 2010. Industry experts include participants and managers of different hybrid forms and agribusiness consultants. Interviews with industry experts followed the same protocol based on a questionnaire with open-ended and closed-ended questions related to how the new organisational forms emerge, the importance of leadership, formality of contracts, incentives, business units, partners, financial issues, etc. The objective was to explain the emergence and evolution of hybrid forms. Secondary information, especially regarding institutional and technological innovations, was obtained from several sources including trade associations, university libraries and the Internet.

\section{Economic liberalisation and the birth of hybrid forms: $1990-2000$}

Until 1990, the agricultural production sector in Argentina was dominated by traditional family farms and farm production was primarily marketed in the domestic market. In order to describe the institutional environment till 1990, Ordóñez and Nichols (2003) explain:

From 1930 to 1991 Argentina alternated weak democracies with strong dictatorships, both political settings sharing a welfare state paradigm with strong state intervention, protectionism, weak rule of law, imports substitution, rampant inflation and hyperinflation.

Nevertheless, with the first socialization of wealth during this period, the model ended with a poor output, low economic growth and low volume of foreign trade $[\ldots]$ The core issue in this paradigm was to allocate the Pampas' productivity and rents to promote urban economy: export taxes on agribusiness output transferred a huge amount of resources to the State that were re-allocated to welfare policies, promoting the local industry for imports substitution. On the other hand, export taxes pushed down agribusiness prices, forcing cheap affordable food for the working class.

This introduction has an explanation: with high levels of intervention in the economy and uncertainty, farmers had few incentives to invest in technology, increase the scale of their farming operations and develop different organisational forms. Agricultural production did not increase at a rapid rate during the period 1950-1990 and Argentina appeared to be left out of the 'green revolution'.

Institutional changes were implemented in the early $1990 \mathrm{~s}$ in order to move away from the high levels of inflation, unemployment and uncertainty of the previous decade. More specifically, the country embarked on dramatic economic liberalisation policies that can be summarised as follows:

- Privatisation of state-owned companies including port and river dredging, railways, oil companies, energy facilities, communications systems, highways and road systems, with subsequent increased private investments. As a result, the country's basic infrastructure was upgraded resulting in lower costs of doing business.

- The enactment of the Convertibility Law (Law 23.928/1991) with the implementation of the currency board that linked the local peso to the US dollar (one peso-one dollar) resulted in a less volatile scenario in terms of inflation and exchange rate.

- Agricultural markets were also liberalised with the elimination of the grain and beef boards and a reduction in State intervention.

- Elimination of export taxes for agricultural commodities and a reduction in import tariffs on farm inputs (e.g. fertilisers, chemicals), which resulted in a significant reduction in distortions between domestic and international prices.

- The enactment of the federal law protecting plant breeder's rights, together with the creation of the CONABIA (Comisión Nacional Asesora de Biotecnología Agropecuaria - the Biotech Commission) and the INASE (Instituto Nacional de Semilla - the National Seed Institute), provided private firms with the necessary protection to develop and introduce new agricultural technologies in Argentina - in particular, new soybean transgenic events were approved.

- The regulation of the trust funds law (fideicomiso), which allowed agricultural financing via the stock exchange market.

Convertibility fixed the currency rate, and effectively nullified the risk of inflation. A more stable environment led farmers to invest in machinery with more production 
capacity. On the other hand, input suppliers faced increased competition. This situation, in addition to a more certain 'business environment', resulted in further relationships between different agents - farmers, land owners, service suppliers, input suppliers, etc. - and great incentives to increase scale in order to reduce unitary costs, coupled with risk-reducing strategies, such as seeding in different regions.

This resulted in the emergence of complex hybrid forms in agricultural production, especially designed to benefit from economies of scale and scope and to take advantage of profitable investment opportunities in the agrifood sector. Consequently, the structure of farming enterprises in Argentina shifted from traditional family-owned resources to agricultural production based on contracts for specialised services, including land leasing contracts, seeding contracts, custom contracts for specific farming activities, harvesting contracts, marketing contracts, future markets contracts, crop insurance contracts, among others.

During this period, two basic hybrid forms emerged: (1) informal hybrid form; and (2) network of networks. Informal hybrid forms basically consist of short-term contractual relationships, mainly informal/verbal agreements, in which farmers participate in a number of transactions for services related to grain and oilseed production (land leases, production inputs, sowing services, weed and insect control, harvesting, commercialisation and storage) (Figure 2).

The network of networks is based on a network of contracts with local partners ('contractors') with specific knowledge. Generally, the whole network is kept in a specific area of influence, but this model has been spread to other regions beyond traditional ones (Figure 3 ).

The coordinating node acts as a central planner, coordinating activities between different network peripheral nodes. Some of these networks have subsequently expanded to other

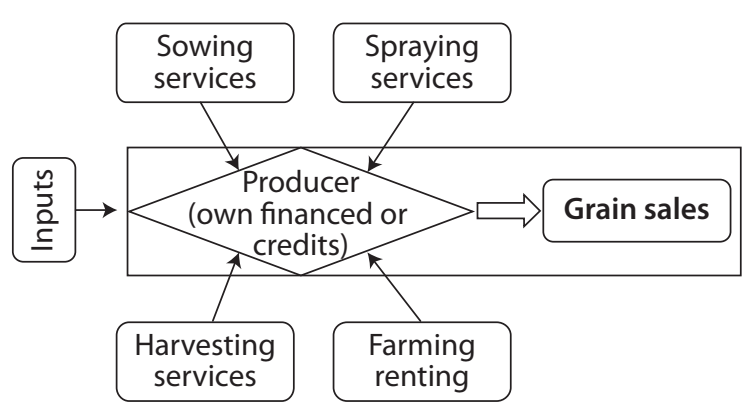

Figure 2. Informal hybrid forms. neighbouring countries, including Brazil, Paraguay, Uruguay and Bolivia. The main characteristics and differences between informal networks and the network of networks are described in Table 1.

The common variable between both hybrid forms was the economy of scale. In the case of the informal hybrid form, higher scales implied the possibility of more intensive use of machinery, thus amortising the investment more quickly and gaining in bargaining power with suppliers and landowners. In the case of a network of networks, the incentive was to spread and diversify the farming area (reducing risk), reduce unitary costs and interact with different types of partners (not only contractors, but also storage service companies).

Also during the 1990s the technological environment saw great innovations with the introduction of no-till farming practices, intensive use of fertilisers, agrochemicals and GM seeds. Moreover, industry players - such as transnationals like ADM, Cargill, Bunge, Dreyfus, Nidera and some other domestic companies such as AGD and Vicentín - also made new investments in modern, large-scale sunflower and soybean processing plants, resulting in higher processing capacity primarily destined for export markets.

\section{Economic crisis and currency devaluation: 2001-2007}

The late 1990s witnessed significant economic turmoil in emerging economies culminating with the 1998 currency devaluation in Brazil, which significantly affected Argentina's competitiveness to export. By the beginning of the twenty-first century, Argentina had not recovered from Brazil's currency devaluation. The federal budget was in a deficit of about $2.5 \%$ of GDP. The government decided to raise tax rates and to adjust the convertibility system pegging the Argentine peso to a currency basket with a 50-50 combination of the dollar and the euro. Investors understood that this adjustment could lead to currency devaluation. Short-term interest rates immediately jumped and a 'silent run' on the banks - with a significant reduction in bank deposits - began in September 2001 (Saxton, 2003).

New and abrupt institutional changes occurred by the end of 2001. The president's demission, followed by a succession of 5 presidents in 2 weeks, created a chaotic scenario. Debt payment to foreign and local bonds holders was suspended, characterising a massive sovereign debt default. On January $1^{\text {st }}$ 2002, Eduardo Duhalde assumed the presidency, determined to reverse free market policies - in particular the convertibility system (Saxton, 2003). Under the Law of 


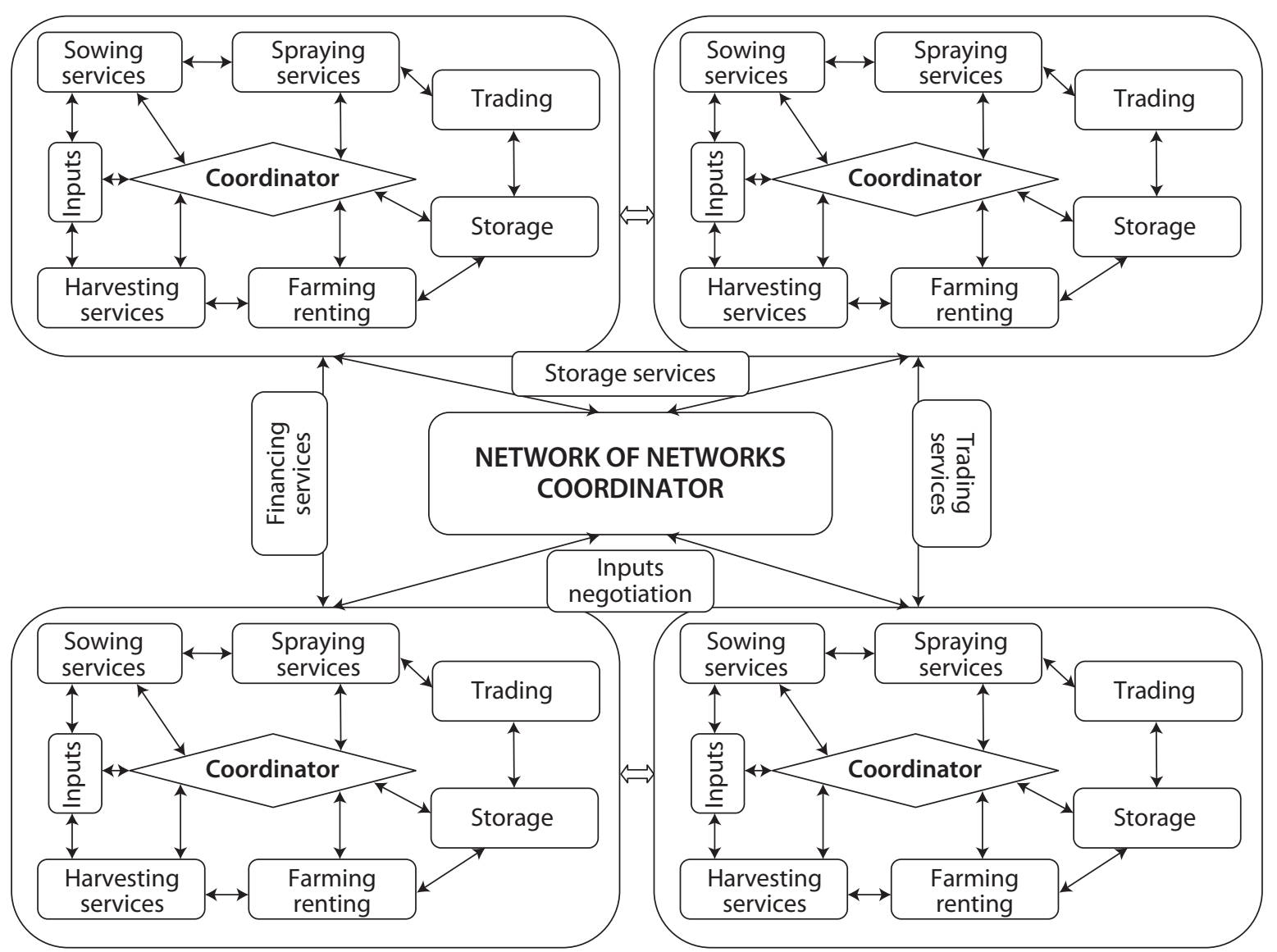

Figure 3. Network of network organization.

Table 1. Main characteristics of the informal hybrid form and network of networks (based on interviews and Chaddad et al. (2009)).

Informal hybrid form

First appearance in Argentina 1990

Contract type

Contract duration

Actors involved

Sources of finance

Average production area

Organizational uncertainty

Leadership

Incentives

Relationship-specific assets
Informal, relational

Short term (one-three years)

Farmers and service suppliers

Farmer's own capital and credit from input suppliers

1,000 to 5,000 hectares (owned and leased land)

Medium

Not really important

Low (due to the impossibility of long term contracts)

Low (know-how)
Network of networks

1995

Both formal and informal (based on trust)

Short and long term (more than 5 years)

Coordinator, land owners, service suppliers,

banks, outside investors

Internal and external, including banks, external investors and input suppliers 20,000-350,000 hectares (mostly leased land)

Very low (importance of trust)

Very important (central coordinator and local managers)

High (participants must fulfil agreements)

High (know-how, reputation of actors, technology) 
Public Emergency and Reform of the Exchange Rate Regime of January 6, 2002 and related measures, the government:

- Ended the convertibility system, in effect confiscating $\$ 14.5$ billion in foreign reserves that, under the convertibility system, were held in trust for the Argentine people and other holders of pesos.

- Devalued the peso from the previous rate of 1 per dollar to 1.40 per dollar, and later floated the exchange rate, allowing further currency depreciation. The peso peaked at \$4 per dollar and stabilised at around \$3 per dollar.

- Forcibly converted bank deposits and loans denominated in US dollars into pesos ('pesification'). Deposits were converted at 1.40 pesos per dollar; loans at 1 peso per dollar. Interest rates were frozen at pre-devaluation levels.

- Forcibly prolonged time deposits (the Spanish name for this measure is the corralón, or big corral, to distinguish it from the earlier corralito). Depositors were unable to freely access their bank accounts and cash withdrawal limits were set at $\mathrm{A} \$ 250$ per week.

- 'Pesified' contracts in dollars at 1 peso per dollar.

- Imposed exchange controls with restrictions on buying foreign currencies.

- Suspended bankruptcy proceedings.

- Established a variety of new taxes and regulations, such as export taxes on agricultural commodities and State controls on exports (similar to those implemented before the 1990s).

Schuler (2002) identified the most pressing problems to be addressed in order for the country to restore economic growth: the currency, the financial system and the tax system. Because economic agents did not trust the currency or the banking system, people were not conducting ordinary transactions such as buying, selling, saving and investing which are necessary to generate economic activity (Ordóñez and Nichols, 2003). On the other hand, funds for credits were almost non-existent.

Despite this chaotic scenario, the agricultural system benefited from currency devaluation. However, by 2002 export taxes were implemented again for the major farm commodities $^{1}$. Because land and trade credit markets froze, financial constraints were widespread among agricultural producers and networks. Margins in agriculture became interesting not only for farmers or contractors, but also for outsiders - regular investors - who did not trust the banking system, which opened the door for agricultural production ventures to offer them investment opportunities. Additional organisational changes were required to allow outside investors to fund agricultural production enterprises, despite the uncertain institutional scenario.

As a result, farmers and financial players developed more complex institutional arrangements and business relationships involving contractors, landowners, input suppliers, processors, exporters and outside investors (some with no previous experience in the sector). Contracts in agriculture provided the level of enforcement that was necessary to include new partners but also to expand and develop the sector.

Two organisational hybrid forms evolved and gained market participation following the 2001 crisis: (1) 'fideicomisos' or agricultural trust funds; and (2) investor-oriented hybrid forms. An agricultural trust fund is a contractual-legal figure enforced by National Law 24,441/1995 (Ley de Fideicomiso

\footnotetext{
${ }^{1}$ By February 2002: sunflower and soybean: $13.5 \%$; wheat and corn: $10 \%$; by july 2002: sunflower and soybean $23.5 \%$; wheat and corn: $20 \%$.
}

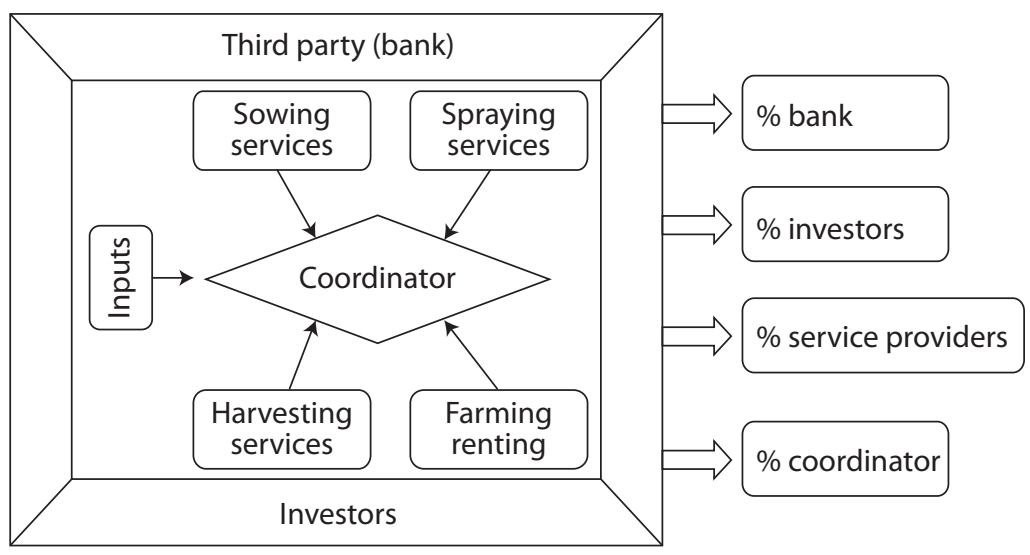

Figure 4. Agricultural trust funds. 
/ Trust-Fund Law). This entity includes an investor and a group of actors linked to an investment capital receiver (the coordinator of the organisation). There is, in turn, a third party (generally a financial institution) which guarantees that the coordinator fulfils contractual obligations to the other trust fund parties without question (Figure 4).

The investor-oriented hybrid form emerged as a mechanism to organise agricultural production using financial resources from several partners. Although often associated with common investment funds, investor-oriented corporate structures appear more private, between producing parties and investing parties (Figure 5).
The main characteristics and differences of agricultural trust funds and investor-oriented hybrids are described in Table 2. The common variable between both hybrid forms was the necessity for financial capital, in order to arrange transparent and enforced contracts that could incentivise investors to participate.

Within the technological environment, there were also significant innovations between 2001 and 2007 with widespread implementation of no-till cropping systems, precision agriculture, intensive use of fertilisers, agrochemicals and genetically modified seeds in the major agricultural regions. The soybean and sunflower crushing capacity continued to expand during this period and so did agricultural commodity exports.

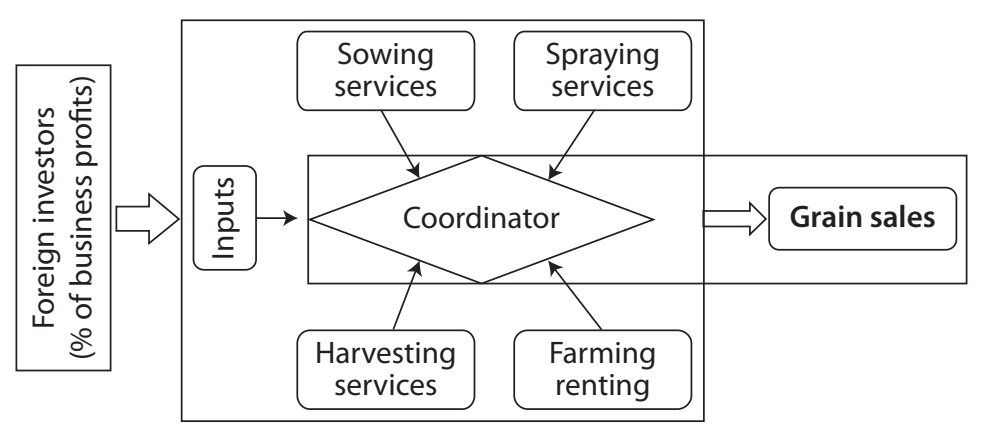

Figure 5. Investor-oriented hybrid form.

Table 2. Main characteristics of agricultural trust funds and investor-oriented hybrids (based on interviews and Chaddad et al. (2009)).

\begin{tabular}{|c|c|c|}
\hline & Agricultural trust funds & Investor-oriented hybrids \\
\hline First appearance in Argentina & Early 2000s & Late 1990 s \\
\hline Contract type & Formal & $\begin{array}{l}\text { Formal and informal (friends and relatives are } \\
\text { part of the business) }\end{array}$ \\
\hline Contract duration & Short to medium term (one-three years) & Short term (one year) \\
\hline Actors involved & $\begin{array}{l}\text { Banks, lawyers, financial organizations, } \\
\text { coordinator (administration company) of } \\
\text { service and contracts with farmers, service and } \\
\text { input suppliers }\end{array}$ & $\begin{array}{l}\text { Coordinator of services-contracts-inputs, } \\
\text { capital investors, lawyers, accountants }\end{array}$ \\
\hline Sources of finance & Institutional and private investors & Ordinary external investors \\
\hline Average production area & $5,000-10,000$ hectares (mainly leased land) & $10,000-100,000$ hectares (leased land) \\
\hline Organizational uncertainty & Low & Low \\
\hline Leadership & Medium & Low \\
\hline Incentives & High & High \\
\hline Relationship specific assets & Medium (know how, reputation of actors) & Medium (know how, reputation of actors) \\
\hline
\end{tabular}




\section{Increased government regulation and uncertainty: 2007-2010}

By the end of 2005, the national government started to regulate agricultural markets and placed restrictions on exports, particularly on bovine livestock (beef and dairy products) and subsequently on wheat. However, the agricultural sector did not suffer significant changes at the institutional level until 2007.

In 2007 and 2008 the international (СВOT) price of soybean - Argentina's main agricultural product - exceeded US $\$ 500$ per ton. International commodity price increases led the government to establish significant changes in export taxes for all agricultural products with Resolution 125 in 2008. This Resolution included the implementation of variable export taxes on commodity exports, thus installing de facto maximum prices for farmers. For instance, when the price of soybean in CBOT was lower than 450 US $\$ /$ ton, the export tax stood at $35 \%$; from that point on, export taxes would vary based on international prices: the higher the price in the Chicago Market, the higher the percentage of the export tax. After many protests and strong resistance from agricultural leaders, the resolution was sent to Congress, where the measure was annulled.

Despite the return to the 1980s export taxes policy and reduction of international commodity prices following the 2008 world financial crisis, interventionist measures on commodity markets continued - including restrictions on wheat and corn exports. Added to this, further institutional changes were the recently sanctioned National Forest Law and Labour Law, which set clearer boundaries for deforestation and protection of natural forests on the one hand and new requirements for employers with heavy restrictions on temporary labour on the other. All these interventions in agriculture resulted in higher overall uncertainty and lower incentives for investment as well as reduced participation from 'outsiders' as financial partners. Companies, banks and individual investors decided not to continue investing in farming, or even reduced their level of investments, due to greater institutional uncertainty. Due to this level of uncertainty, there have been notorious cases of exporters and crushing companies going upstream towards farming (be it through vertical integration or coordination) in order to ensure sufficient supplies to feed an increased crushing capacity (which currently stands at around 55 million tons).

During this period, the hybrid forms that continued in force were the network of networks and informal hybrid forms, shifting to short-term contracts. The other hybrid forms decreased in importance as farming in the late $2000 \mathrm{~s}$ did not offer sufficiently high returns given the exceedingly high levels of uncertainty, especially for outside investors. Network of networks and investor-oriented hybrid forms have started addressing (although incipiently) the issue of sustainability to some degree, and this can be seen in the increasing number of hectares that have been certified under some form of sustainability protocol (be it social or environmental).

At the technological level, investments in machinery and input use were considerably reduced (despite the incentive towards technification that arose from the new labour law). In addition, farmers shifted to crops with lower intervention and investment needs (such as soybeans), while less efficient farmers withdrew from marginal and riskier production areas. Furthermore, many farmers decided to postpone marketing their crops because of institutional uncertainty and fiscal controls.

\section{Discussion}

An analysis of the institutional, organisational and technological environments allowed us to understand the evolution of farming and agribusiness in Argentina during different periods. It is also important, however, to examine what happened during these periods from the point of view of agricultural production and investments.

Figure 6 shows the total agricultural production between 1993/94 and 2010/11. During the first period of analysis (1990-2001) there was a constant growth in production due to both cultivated area growth and increases in productivity as a result of the intensive use of fertilisers and inputs and machinery, the use of GM seeds and greater expansion of cultivated area due to the new organisational forms described. Institutional certainty, contracts, new business models, and technology availability resulted in enhanced production and productivity. From the 2001 crisis to the 2003/04 season production remained fairly stable, especially because of institutional uncertainty and difficulties for farmers to access credit markets. However, production returned to a gradual growth mode until the 2007/08 season. Following the institutional changes in 2008, there was a very strong reduction in production and productivity due to a reduction in the planted area and a severe drought in 2009, and an increase in the soybean area.

Following this statement, there would be a strong relationship between the level of institutional uncertainty and investments by agricultural players (Table 3 ). During the 1990s, the Convertibility Law and no export taxes generated 


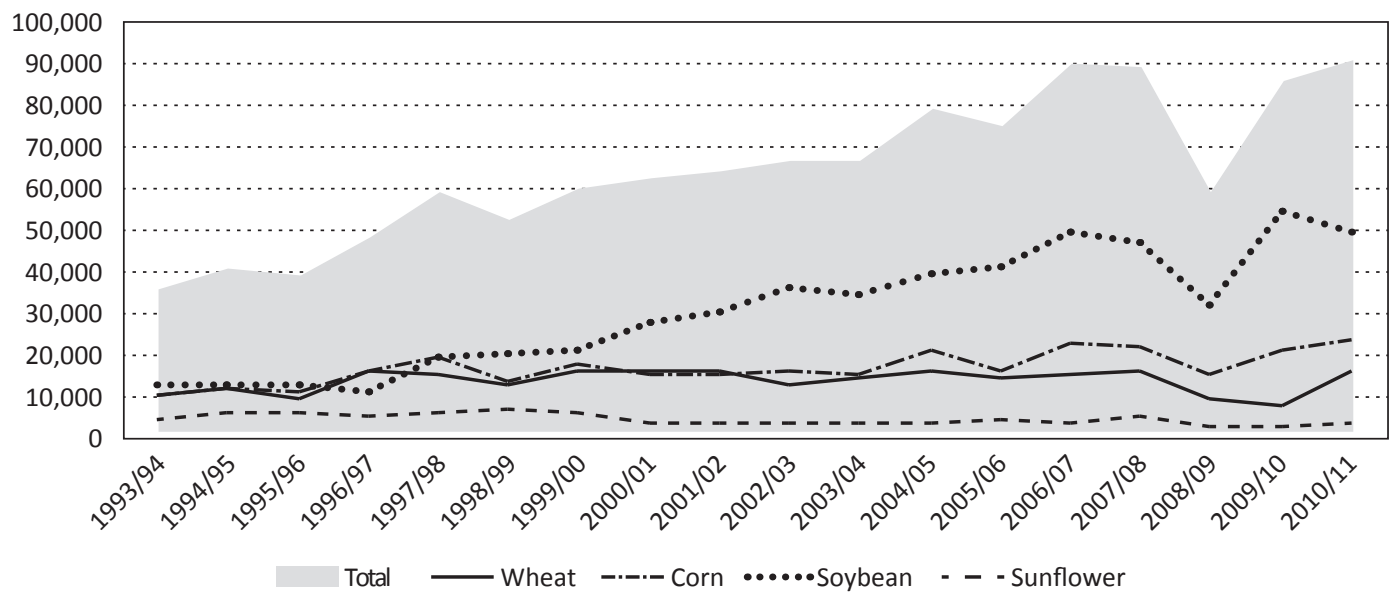

Figure 6. Total production of the four main crops (in thousands tons) (1993/94-2010/11) (based on official data by SAGPyA).

a more certain environment resulting in investments in machinery (no till seeding), GMO and the use of fertilisers and agrochemicals in general. Moreover, during this period there were incentives to invest in crushing capacity, from 8.2 million tons in 1993 to 30 million in 2000.

The new organisational forms (with higher scales) emerged during this decade in order to take advantage of the higher capacity of machinery and to reduce costs (especially fixed costs). But the hybrid forms became possible because of reduced institutional uncertainty and low transaction costs in terms of concluding contracts between different agents. Following Coase's statement, low uncertainty corresponded to the incentives necessary to develop agriculture in Argentina, investing in new technology; but also, agents were willing to do business together due to lower transaction costs.

Despite the 2001/2002 political/financial crisis - with high levels of macro transaction costs -, players had experimented with collective actions and the need for financial capital opened the door to new players: investors. Hence, the institutional arrangements (Coase, 1937) reduced transaction uncertainty, resulting in more investments, higher production and productivity, and the expansion of agriculture to new regions.

Moreover, between 2004 and 2006, lower institutional uncertainty led to new investments to expand processing capacity, which also involved improvements in storage and handling infrastructure (such as harbours and storage facilities). By 2008, oilseed processing capacity surpassed 55 million tons with an average capacity use of $70 \%$, and soybean represented $87 \%$ of the processing volume (Hinrichsen, 2009).

However, new government interventions (2008) generated lower incentives for agriculture; area, production and productivity became stable and investors decided not to continue financing agribusiness activities. Moreover, some companies (especially those on a larger scale) decided to reduce the area (because of higher monitoring costs and rental costs) or even increase their participation in farming in other countries. Informal hybrid forms continued operating due to their flexibility, short-term contracts and smaller scales.

\section{Conclusions}

In this paper the authors described and analysed the evolution of the institutional, organisational and technological environments in Argentine agriculture since the 1990s. During this period, there were different institutional contexts, sometimes with clearer and more stable conditions and low levels of uncertainty, sometimes with higher intervention policies. The paper discussed how new organisations emerged during the different periods and scenarios, in a context of increased international demand for agricultural commodities.

Starting with organisational innovations of the 1990s, farmers, service providers and input suppliers developed complex contracting systems and networks in order to expand agricultural production. Following the Argentine economic crisis in 2001 and 2002, these actors also started to create alliances with other actors outside the formal agribusiness circuit (investors). Common people - and, 
Table 3. Discussion of results: institutional environment, effects and organisational form.

\begin{tabular}{|c|c|c|c|c|c|c|}
\hline \multirow[t]{2}{*}{ Characteristics } & \multicolumn{5}{|l|}{ Hybrid forms } & \multirow{2}{*}{$\begin{array}{l}\text { Institutional } \\
\text { scenarios }\end{array}$} \\
\hline & $\begin{array}{l}\text { Informal hybrid } \\
\text { form }\end{array}$ & Network of networks & $\begin{array}{l}\text { Investor-oriented } \\
\text { hybrids }\end{array}$ & $\begin{array}{l}\text { Agricultural trust } \\
\text { fund }\end{array}$ & & \\
\hline Contract type & Informal (trust) & $\begin{array}{l}\text { Formal \& informal } \\
\text { (trust) }\end{array}$ & & & \multirow{3}{*}{ 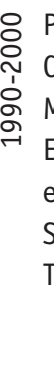 } & \multirow{3}{*}{$\begin{array}{l}\text { Privatization } \\
\text { Convertibility Law } \\
\text { Market liberalization } \\
\text { Elimination of } \\
\text { export taxes } \\
\text { Seed law } \\
\text { Trust fund law }\end{array}$} \\
\hline $\begin{array}{l}\text { Contract } \\
\text { duration }\end{array}$ & Short & $\begin{array}{l}\text { Short (landowners); } \\
\text { Long (other network } \\
\text { members) }\end{array}$ & & & & \\
\hline Incentives & $\begin{array}{l}\text { Lower institutional } \\
\text { uncertainty: higher } \\
\text { incentives to gain } \\
\text { scale }\end{array}$ & $\begin{array}{l}\text { Lower institutional } \\
\text { uncertainty: higher } \\
\text { incentives to gain } \\
\text { scale }\end{array}$ & & & & \\
\hline Contract type & Informal (trust) & $\begin{array}{l}\text { Formal \& informal } \\
\text { (trust) }\end{array}$ & $\begin{array}{l}\text { Formal \& informal } \\
\text { (trust) }\end{array}$ & Formal & & \multirow{3}{*}{$\begin{array}{l}\text { End of convertibility } \\
\text { Currency } \\
\text { devaluation } \\
\text { Pesification } \\
\text { Corralón } \\
\text { Exchange controls } \\
\text { Reinstatement of } \\
\text { export taxes }\end{array}$} \\
\hline $\begin{array}{l}\text { Contract } \\
\text { duration }\end{array}$ & Short & $\begin{array}{l}\text { Short (landowners); } \\
\text { Long (other network } \\
\text { members) }\end{array}$ & Short & $\begin{array}{l}\text { Short to medium } \\
\text { term (one-three } \\
\text { years) }\end{array}$ & & \\
\hline Incentives & $\begin{array}{l}\text { Institutional } \\
\text { uncertainty: higher } \\
\text { economic incentives } \\
\text { (higher margins } \\
\text { due to currency } \\
\text { devaluation) }\end{array}$ & $\begin{array}{l}\text { Institutional } \\
\text { uncertainty: higher } \\
\text { economic incentives } \\
\text { (higher margins } \\
\text { due to currency } \\
\text { devaluation) }\end{array}$ & $\begin{array}{l}\text { Institutional } \\
\text { uncertainty: higher } \\
\text { economic incentives } \\
\text { (higher margins } \\
\text { due to currency } \\
\text { devaluation) }\end{array}$ & $\begin{array}{l}\text { Institutional } \\
\text { uncertainty: higher } \\
\text { economic incentives } \\
\text { (higher margins } \\
\text { due to currency } \\
\text { devaluation) }\end{array}$ & & \\
\hline Contract type & Informal (trust) & $\begin{array}{l}\text { Formal \& informal } \\
\text { (trust) }\end{array}$ & Formal & & \multirow{3}{*}{\multicolumn{2}{|c|}{ 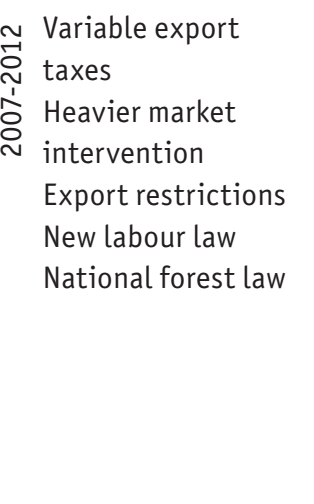 }} \\
\hline $\begin{array}{l}\text { Contract } \\
\text { duration }\end{array}$ & Short & $\begin{array}{l}\text { Short \& Medium } \\
\text { (landowners); Long } \\
\text { (other network } \\
\text { members) }\end{array}$ & Short & & & \\
\hline Incentives & $\begin{array}{l}\text { Institutional } \\
\text { uncertainty: lower } \\
\text { economic incentives } \\
\text { (lower margins due } \\
\text { to governement } \\
\text { intervention) }\end{array}$ & $\begin{array}{l}\text { Institutional } \\
\text { uncertainty: lower } \\
\text { economic incentives } \\
\text { (lower margins due } \\
\text { to governement } \\
\text { intervention) }\end{array}$ & $\begin{array}{l}\text { Institutional } \\
\text { uncertainty: lower } \\
\text { economic incentives } \\
\text { (lower margins due } \\
\text { to governement } \\
\text { intervention) }\end{array}$ & & & \\
\hline
\end{tabular}

to a lesser extent, banks and financial organisations began to finance the agricultural sector. After the 2008 agricultural crisis, new organisational forms emerged with the participation of processors and exporters.

The description and interpretation of organisational adaptation in a context of institutional uncertainty explains why Argentina is in a unique position not only because of its natural resources, but also because of the capacity of the agrifood system participants to manage their businesses with different types of formal and informal contracts in turbulent institutional scenarios. These hybrid forms provided the institutional framework necessary to reduce transaction costs and build trust among agents in such a way that contracts and exchange could continue to occur in a highly uncertain institutional environment. 
The hybrid forms emerged to create order and enforce property rights among agrifood system participants, which in turn enabled them to benefit from the commodity cycle and profitable investment opportunities. Hybrid forms constitute autonomous specialised nodes that work in a coordinated fashion assisted by modern information and communication technologies, trust, a shared vision, and the capacity to coordinate different agricultural processes. These organisations are more competitive because they enjoy aligned incentives, flexibility, and adaptability.

As farmers continue to face new institutional and technological challenges, they will continue to tinker with alternative hybrid forms to reduce the costs of doing business in a fragile institutional environment.

\section{References}

Bonoma, T.V., 1985. Case research in marketing: opportunities, problem and process. Journal of Marketing Research, 22: 119-208.

Chaddad, F., S.I. Senesi, F. Vilella and H. Palau, 2009. The emergence of hybrid forms in Argentina's grain production sector. Paper presented at IAMA Conference, Budapest, Hungary. June. Available at: http://www.eoq.hu/iama/conf/1125_paper.pdf.

Coase, R., 1937. The nature of the firm. Economica, 4: 386-405.

Gil, A.C., 1994. Métodos e técnicas de pesquisa social. $4^{\text {th }} \mathrm{ed}$. Atlas, São Paulo, Brazil.

Hinrichsen, 2009. Anuario no. 44. JJ Hinrichsen SA; CorredorBroker, Buenos Aires, Argentina.

Joskow, P.L., 1995. The new institutional economics: alternative approaches. Journal of Institutional and Thoretical Economics, 155/1: 248-259.

Joskow, P.L., 2004. New institutional economics: a report card. Essay based on Joskow's presentation at the Annual Conference of International Society of New Institutional Economics, Budapest, Hungary, September 2003. Available at: http://economics.mit. edu/files/1171.

Kherallah, M. and J. Kirsten, 2001. The new institutional economics. Application for agricultural policy research in developing countries. Markets and Structural Studies Division. International Food Policy Research Institute, Washington, DC, USA.

Ménard, C., 2004. The economics of hybrid organizations. Journal of Institutional and Theoretical Economics, 160: 345-376.

North, D.C., 1990. Institutions, institutional change and economic performance. Cambridge University Press, Cambridge, UK.

Ordóñez, H. and J. Nichols, 2003. Los grobo case. Texas A\&M University, College Station, TX, USA.

Peterson, H.C., 2011. An epistemology for agribusiness: peers, methods and engagement in the agri-food bio system. International Food and Agribusiness Management Revieuw, 14(5): 11-26.
Saxton, J., 2003. Argentina's economic crisis: causes and cures. Joint Economic Committee United States Congress, Washington, DC, USA.

Schuler, K., 2002. Fixing Argentina. Policy Analysis no. 445. CATO Institute, Washington, DC, USA, 36pp.

Williamson, O.E., 1991. Comparative economic organization: the analysis of discrete structural alternatives. Administrative Science Quarterly, 36(2): 269-296.

Williamson, O.E., 2000. The new institutional economics: taking stocks, looking ahead. Journal of Economics Literature, 38: 595613.

Yin, R.K., 1989. Case study research: design and methods. SAGE Publications, Newbery Park, CA, USA.

Zylbersztajn, D., 1996. Governance structures and agribusiness coordination: a transaction costs economics based approach. In: Goldberg, R. (ed.) Research in domestic and international agribusiness management. Vol. 12. Graduate School of Business Administration. Harvard University, Boston, MA, USA, pp. 245-310.

Zylbersztajn, D., 1999. Strictly coordinated food systems: exploring the limits of the coasian firm. International Food and Agribusiness Management Review, 2(2): 249-265. 